\title{
Pengaruh Model Aplikasi Control Diabetes Mellitus Type 2 (CDMT2) Terhadap Kualitas Hidup Pada Pasien Diabetes Mellitus Tipe 2
}

\author{
Ida Faridah ${ }^{1}$, Yati Afiyanti ${ }^{2}$ Ade Purnama ${ }^{3 *}$ \\ ${ }^{1,3}$ STIKes Yatsi Tangerang, ${ }^{2}$ Fakultas Keperawatan, Universitas Indonesia \\ *Email: adeprnm98@gmail.com
}

\begin{abstract}
Background: Diabetes mellitus type 2 is incurable but can be controlled by control blood sugar and improves the quality of life of diabetics. The prevalence of diabetes mellitus based on the diagnosis of doctors and the age of $\geq 15$ years in Banten Province increased in 2013 by $1.3 \%$ while in 2018 by 2.2\% (Riskesdas, 2018). The purpose of this study was to find out the effects of the CDMT2 application model on the quality of life of patients with type 2 diabetes mellitus. Methods: The method in this study is one group of pretest posttest. Sampling techniques in this study used total sampling with a total of 384 respondents with type 2 diabetes mellitus in Banten. The instruments used were the DQOL questionnaire and the cdmt 2 application model. Results: Results from quantity analysis using Simple Paired T-Test showed the influence of cdmt2 application model on the quality of life of DM sufferers (value $P=0.000$ ) $P<0.05$. Cdmt2 application has a real effect on the quality of life of dm type 2 sufferers. Conclusion: The Cdmt2 application model has a noticeable effect on the quality of life of people with type 2 diabetes mellitus health promotion related to type 2 diabetes mellitus.
\end{abstract}

Keywords: CDMT2, diabetes mellitus, quality of life

\section{PENDAHULUAN}

Menurut "Internasional Diabetes Federation (IDF) Diabetes Atlas $8^{\text {th }}$ Edition", diperkirakan 15,5 juta orang dewasa berusia 20-27 tahun hidup dengan diabetes di wilayah Afrika pada tahun 2017, mewakili regional 3,3\%. Prevalensi diabetes tertinggi di wilayah ini ditemukan pada orang dewasa berusia sekitar 20-27 tahun, hidup dengan diabetes. Diwilayah asia tenggara pada 2017, mewakili prevalensi regional 8,5\%. Sekitar 45,8\% dari kasus diabetes ini tidak terdiagnosis. Hampir setengah $48,8 \%$ dari semua orang dewasa dengan diabetes di wilayah tersebut tinggal di daerah perkotaan (IDF (International Diabetes Federation) 2017).

America Diabetes Association (ADA) pada tahun 2018 di perkirakan 30,3 juta orang dari semua jenis usia atau 9,4\% dari populasi Amerika Serikat menderita diabetes. Total ini termasuk 30,2 juta orang dewasa berusia 18 tahun atau lebih $12,2 \%$ dari semua orang dewasa di Amerika Serikat, yang 7,2 juta 23,8\% tidak mengetahui atau tidak melaporkan memiliki diabetes. Presentase orang dewasa dengan diabetes meningkat dengan bertambahnya usia, mencapai tinggi $25,2 \%$ di antara mereka yang berusia 65 tahun (Trikkalinou, Papazafiropoulou, and Melidonis 2017)

Berdasarkan hasil data dari Riskesdas pengendalian diabetes mellitus di Indonesia mengalami kenaikan provinsi pada tahun 2018 mengalami kenaikan pada tahun 2013 sebanyak 6,9\% sedangkan ditahun 2018 sebanyak 8,5\% . hasil prevalensi diabetes mellitus berdasarkan pada penduduk dengan usia lebih dari 15 tahun yang di diagnosis oleh dokter. Prevalensi diabetes mellitus di provinsi NTT hasil diagnosis dokter pada penduduk umur lebih dari 15 tahun memiliki hasil terrendah yakni sebesar $0,9 \%$, sedangkan provinsi DKI Jakarta memiliki prevalensi paling tinggi sebesar 
$3,4 \%$, prevalensi diabetes mellitus di provinsi Banten mengalami peningkatan pada tahun 2013 sebanyak 1,3\% sedangkan pada tahun 2018 sebanyak 2,2\% (Riskesdas 2018).

Diabetes melitus ialah gangguan metabolik yang berjalan kronik progresif (lama dan bertambah parah) yang ditandai dengan kadar glukosa darah tinggi dan gangguan metabolisme karbohidrat, lemak, dan protein, yang disebabkan oleh banyak faktor, seperti kerja insulin terganggu, gpengeluaran inslunin yang terganggu, atau bahkan keduanya (Yahya 2018).

Kualitas hidup

ialah menggambarkan rasa bahagia serta rasa puas penderita diabetes dalam melakukan kegiatan sehari-hari secara mandiri (Zainuddin, Utomo, and Herlina 2015). Sebagai patokan dalam suatu penyakit kronik kualitas hidup sering di pakai sebagai penentu penyakit kronik (Brillianti, 2016). Kualitas hidup penderita DM dipengaruhi oleh beberapa faktor antara lain, pendidikan, ekonomi, lama sakit dan komplikasi.

Pentingnya meningkatkan kualitas hidup pasien $\mathrm{dm}$ dikarenakan kulitas hidup sangat berpegangan erat dengan respon terhadap terapi, perkembangan penyakit dan bahkan kematian akibat dm. Dalam studi sebelumnya didapatkan bahwa, penerimaan seseorang akan kesehatannya sebagai prediktor independent kesakitan dan kematian pasien yang mengalami gagal ginjal, dimana $60 \%$ dari pasien tersebut adalah pasien DM. Semakin rendah kualitas hidup seseorang, semakin tinggi resiko kesakitan dan bahkan kematian.

CDMT2 atau Control Diabetes mellitus tipe 2 merupakan model aplikasi berbentuk mobile yang bisa digunakan di setiap smartphone dimana aplikasi ini bertujuan untuk mengontrol kadar gula darah pasien penderita diabetes mellitus khusunya tipe 2 dengan cara memasukan hasil pemeriksaan kadar gula darah dimana nanti di dapatkan hasil bahwa jika gula darah tinggi akan muncul fitur-fitur untuk informasi untuk menstabilkan kadar gula darah dalam tubuh dengan konsep Quality Of Life pada pasien dm dimana pasien bisa mengontrol sendiri kadar gula darah sesuai dan dapat meningkatkan kualitas hifup pasien itu sendiri.

Karena semakin tingginya penderita diabetes di banten maka dari itu peneliti memutuskan untuk melakukan penelitian dengan membuat model aplikasi yang digunakan untuk membantu mengontrol kualitas hidup pasien diabetes.

\section{METODE PENELITIAN}

Metode yang digunakan dalam penelitian ini yakni one group pretest and post test. Populasi yang digunakan yaitu seluruh pasien yang mengalami penyakit diabetes mellitus di Banten. Penelitian ini memiliki jumlah sampel sebanyak 384 orang, cara menentukan sampel dengan rumus Lemeshow. Penelitian ini dilakukan di Banten pada bulan juni-juli 2020. Peneliti menerapkan semua etik penelitian pada setiap kegiatan penelitian yang melibatkan peneliti dan subjek penelitian. Penelitian ini telah mendapatkan Ethical Approval dari komisi Etik Penelitian LPPM STIKes Yatsi Nomor:046/LPPM-STIKES YATSI/IV/2020

Variabel bebas (Independent) adalah penggunaan model aplikasi DMT2. Variabel terikat (Dependent) adalah kualitas hidup penderita Diabetes Mellitus. Instrument yang digunakan ialah kuesioner Quality of Life Variabel bebas 
(Independent) adalah penggunaan model aplikasi DMT2. Variabel terikat (Dependent) adalah kualitas hidup penderita Diabetes Mellitus, dengan mengisi berupa pertanyaan dalam kuesioner pre test, jika skor yang di peroleh tinggi maka semakin besar tingkatan kualitas hidup pasien $\mathrm{dm}$. Kuesioner berisi beberapa pertanyaan untuk menentukan tingkatan skor pasien dalam hal kualitas hidup dan dibagikan menggunakan link google form, dan setelah mengisi pretest pasien akan diberikan link untuk mendownload aplikasi cdmt2, penerapan pemakaian aplikasi ini dilakukan selama 3 minggu dengan catatan pasien selalu aktif mengisi dan menggunakan aplikasi dan mengikuti instruksi yang disarankan oleh cdmt2 setelah itu pasien melakukan pengisian ulang kuesioner post test.

\section{HASIL PENELITIAN}

Tabel 1. Distribusi Rata-Rata Usia Pasien DM

\begin{tabular}{|c|c|c|}
\hline Usia & Fruekuensi & Presentasi (\%) \\
\hline$<34$ tahun & 186 & 48,4 \\
\hline$>34$ tahun & 198 & 51,6 \\
\hline Total & 384 & 100 \\
\hline
\end{tabular}

Tabel 2. Distribusi Rata-Rata Jenis Kelamin Pasien DM

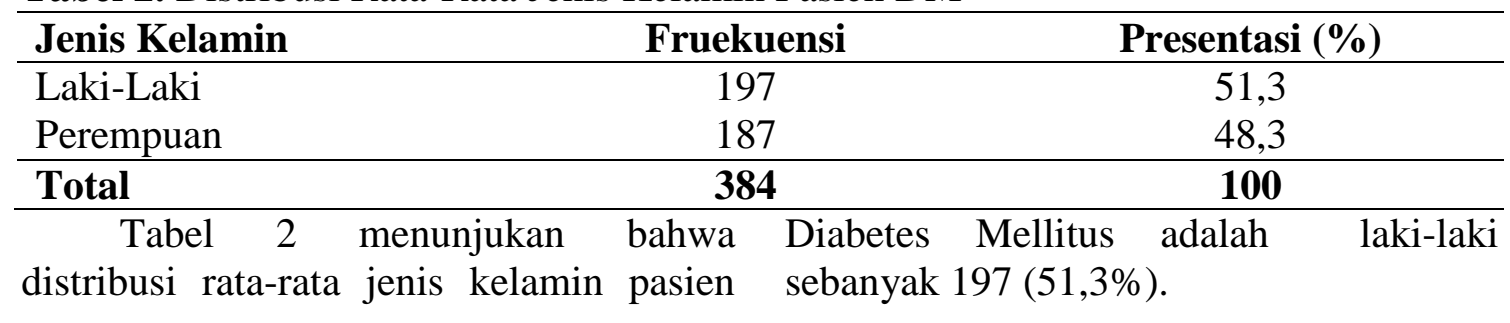

Tabel 3. Distribusi Rata-Rata Pasien DM Memiliki Tingkat Pendidikan

\begin{tabular}{|c|c|c|}
\hline Pendidikan & Frekuensi & Presentase (\%) \\
\hline SD/tidak bersekolah & 57 & 14,8 \\
\hline SMP & 38 & 9,9 \\
\hline SMA & 280 & 72,9 \\
\hline Perguruan tinggi & 9 & 2,4 \\
\hline Total & 384 & 100 \\
\hline
\end{tabular}


Tabel 4. Distribusi Frekuensi Lama Menderita

\begin{tabular}{|c|c|c|}
\hline Lama Menderita Diabetes & Frekuensi & Presentase $(\%)$ \\
\hline$<6$ tahun & 185 & 48,2 \\
\hline$>6$ tahun & 199 & 51,8 \\
\hline Total & 384 & 100 \\
\hline
\end{tabular}

Tabel 5. Distribusi Kualitas Hidup Sebelum Dan Sesudah Menggunakan Aplikasi CMDT2

\begin{tabular}{|c|c|c|c|c|}
\hline \multirow{2}{*}{ Kualitas Hidup Pasien } & \multirow{2}{*}{$\frac{\text { Sebelum }}{\mathrm{N}}$} & \multicolumn{3}{|c|}{ Sesudah } \\
\hline & & $\%$ & $\mathbf{n}$ & $\%$ \\
\hline Rendah & 262 & 68,2 & 10 & 2,6 \\
\hline Sedang & 122 & 31,8 & 222 & 57,8 \\
\hline Tinggi & - & & 152 & 39,6 \\
\hline Total & 384 & 100,0 & 284 & 100,0 \\
\hline
\end{tabular}

Tabel 6. Distribusi Nilai Pre Test dan Post Test

\begin{tabular}{lcc}
\hline Variabel & Statistic & Std.Eror \\
\hline Pre Test & -.044 & .125 \\
Post Test & -.224 & .125 \\
\hline Tabel 6 Distribusi diketahui bahwa & dan post test berdistribusi normal karena \\
variable pre test mempunyai nilai statistic & nilai diatas -2 sampai +2.
\end{tabular}

sebesar -044 dan post sebesar -224 pre test

Tabel 7. Distribusi Hasil Analisa Bivariat

\begin{tabular}{cccccccc}
\hline Variabel & Perlakukan & N & Mean & SD & Min & Max & P-Value \\
\hline Pengaruh Aplikasi & Pre Test & 384 & 56.58 & 11,9 & & & \\
CDMT2 & Post Test & 384 & 89.19 & & & & \\
& PDT & & & & \\
\hline
\end{tabular}
nilai mean 56,58 dan setelah berusia $<35$ tahun $186(48,4 \%)$. Dari hasil menggunakan aplikasi didapatkan nilai penelitan oleh (Adri et al. 2020) umumnya mean 89,19. Hasil statistic diketahui usia $>45$ tahun 11,183 kali mempunyai bahwa nilai $(P$ Value $)$ sebesar $0,000<$ resiko lebih terkena kasus diabetes melitus 0,005 .

\section{PEMBAHASAN}

Berdasarkan tabel 1 terlihat bahwa responden terbanyak yaitu berusia >35 tahun yaitu sebanyak 198 responden tipe 2, sedangkan menurut penelitian dari (Faida, Dyah, and Santik 2020) usia diatas 30 tahun lebih banyak menderita diabetes melitus dan mengarah pada diabetes mellitus tipe 2. Makin bertambah umur maka memiliki resiko diabetes makin 
tinggi hal ini disebebkan hormon insulin yang diproduksi terjadi penurunan (Luthfa and Fadhilah 2019). Menurut asumsi peneliti, makin bertambahnya usia maka semakin menurun kesadaran untuk mengontrol gula darah dan bisajuga akibat gaya hidup yang sangat tidak sehat akibatnya sulit mengatur gula darah. Berdasarkan tabel 2 terlihat bahwa 384 responden, responden laki-laki lebih banyak 197 Responden dengan presentase $(51,3 \%)$ dan responden perempuan lebih sedikit sebanyak 187 Responden dengan presentase $(48,7 \%)$.

Hasil dari penelitian Kim YJ et al., (2018) dapat disimpulkan sebagain besar responden didapatkan hasil dalam penelitiannya yaitu perempuan sebanyak 49,56\% dari 799 responden yang diteliti. Hasil serupa dikemukakan oleh Lutfa (2019) didapatkan hasil bahwa sebagian besar responden perempuan yaitu sebanyak 78,8\% dari 118 responden yang diteliti. Menurut Kemenkes (2019) Teori yang mengemuka adalah laki-laki lebih sensitif pada insulin dari pada perempuan. Selain itu, tubuh pria juga menyimpan lemak di sekitar organ, bukan di bawah kulit seperti wanita (visceral fat deposition).

Berdasarkan Tabel 3 menunjukan dari 384 responden, Tingkat pendidikan tertinggi adalah SMA sebanyak 280 Responden dengan presentase $(72,9 \%)$. Perbedaan terdapat dari hasil penelitian Nauri 2016, dimana dalam pendidikannya mayoritas responden berpendidikan rendah yaitu sebanyak 56,25\%. Hasil serupa dikemukakan oleh Lutfa (2019) dimana dalam penelitiannya nayoritas responden berpendidikan SD yaitu sebanyak 63,6\% dari 118 responden yang diteliti. Menurut Stipanovic "(2002 dalam Yusra, 2010)" menyatakan bahwa pendidikan ialah indicator faktor penting untuk pasien diabetes mellitus agar dapat mengerti serta melakukan manajemen dengan mandiri. Peneliti berasumsi bahwa pengetahuan dan sarana informasi berkaitan dengan tingkat pendidikan seseorang.

Hasil Tabel 4 menunjukan dari 384 responden, lama menderita diabetes $>6$ tahun yakni sebanyak 199 responden dengan presentase $(51,8 \%)$, dan $<6$ tahun sebanyak 185 responden dengan presentase $(48,2 \%)$.

Hasil penelitian tersebut sama seperti penelitian Kim YJ et.al (2019) dimana mayoritas responden telah mengalami diabetes lebih dari 5 tahun, dengan rata-rata menderita sudah 8 tahun sebanyak 74,3\%. Hasil serupa dikemukakan oleh Nuari (2016) dimana sebagain besar responden penyakit DM dalam waktu 6-10 tahun. Salah satu factor yang menjadi pengaruh kualitass hidup pasien diabetes yakni lama mengidap penyakit diabetes tersebut. "Reid \& Walker (2009) dalam Yusra (2010)" mengatakan tingkat kecemasan berakibat terhadap penurunan kualitas hidup pasien dengan DM akibat lamanya menderita diabetes.

Hasil dari penelitian didapat sebelum menggunakan aplikasi mayoritas responden mempunyai kualitas hidup rendah yakni sebanyak 262 responden $(68,2 \%)$. Sesudah menggunakan aplikasi terdapat peningkatan kualitas hidup responden yaitu mayoritas responden mempunyai kualitas hidup sedang 222 responden $\quad(57,8 \%)$.Hasil statistic diketahui nilai $(P$ Value) sebesar $0,000<$ 0,005 , dapat disimpulkan bahwa terdapat perbedaan signifikan sebelum dan sesudah menggunakan aplikasi CDMT2 terhadap 
peningkatan kualitas hidup pasien Diabetes Melitus Tipe 2.

Aplikasi tersebut di berikan kepada responden untuk di unduh dan di ralisasikan selama 3 minggu. Aplikasi CMDT2 berisi tentang informasi mengenai masalah kesehatan Diabetes Melitus tipe 2, record gula darah serta pendidikan kesehatan mengenai makanan yang dianjurkan dan olahraga yang dianjurkan untuk pasien diabetes mellitus.

Menurut asumsi peneliti aplikasi CDMT2 bermanfaat untuk mengontrol kadar gula darah klien dengan diabetes dan meningkatkan kualitas hidup pada klien yang menggunakannya.

\section{KESIMPULAN DAN SARAN}

Berdasarkan hasil analisis data dan pembahasan yang telah dilakukan, maka dapat peneliti simpulkan bahwa hasil analisis statistik menunjukkan Aplikasi CDMT2 berpengaruh dalam meningkatkan kualitas hidup pasien dengan dm type 2 .

Saran untuk penelitian selanjutnya yakni lebih mengembangkan aplikasi ini kembali agar bisa dimanfaatkan oleh semua kalangan masyarakat dan berguna untuk fasilitas kesehatan.

\section{DAFTAR RUJUKAN}

Adri, Khaeriyah, Arsunan Arsin, Ridwan $M$ Thaha, and Andi Hardianti. (2020). Faktor Risiko Kasus Diabetes Mellitus Tipe 2 Dengan Ulkus Diabetik Di Rsud Kabupaten Sidrap Risk Factors Of Diabetes Mellitus Type 2 With Diabetic 3(1): 101-8.

Faida, Awaliyah Nor, Yunita Dyah, and Puspita Santik. (2020). Higeia Journal Of Public Health 4(1): 3342.
IDF (International Diabetes Federation). (2017). IDF Diabetes Atlas, 8th edition Eighth Edition 2017. file:///Users/ximeneacarballo/Downlo ads/IDF_DA_8e-EN-final.pdf

Luthfa, Iskim, and Nurul Fadhilah. (2019). Self Management Menentukan Kualitas Hidup Pasien Diabetes Mellitus 4(2): 397-405.

Riskesdas, Kemenkes. (2018). Hasil Utama Riset Kesehata Dasar (RISKESDAS). Journal of Physics A: Mathematical and Theoretical 44(8): 1-200. http://arxiv.org/abs/1011.1669\%0Aht tp://dx.doi.org/10.1088/17518113/44/ 8/085201\%0Ahttp://stacks.iop.org/17 $518121 / 44 / \mathrm{i}=8 / \mathrm{a}=085201$ ? $\mathrm{key}=\mathrm{crossr}$ ef.abc74c979a75846b3de48a5587bf7 $08 \mathrm{f}$.

Trikkalinou, Aikaterini, Athanasia K Papazafiropoulou, and Andreas Melidonis. (2017). Type 2 Diabetes and Quality of Life. World Journal of Diabetes.

Yahya, Nadjibah. (2018). Hidup Sehat Dengan Diabetes. Tiga Serangkai. Jakarta

Zainuddin, Mhd, Wasisto Utomo, and Herlina. (2015). Hubungan Stres Dengan Kualitas Hidup Penderita Diabetes Mellitus Tipe 2. Jurnal Online Mahasiswa Program Studi Ilmu Keperawatan Universitas Riau 2(1): 890-98. https://www.peneliti.com/publication s/188387/hubungan-stres-dengankualitas-hidup-penderita-diabetesmellitus-tipe-2. 